\title{
EFFECT OF YOGA RELAXATION EXERCISE USING ANDROID APPLICATION ON DYSMENORRHEA AMONG FEMALE ADOLESCENTS IN YOGYAKARTA
}

\author{
Desi Fitriani'), Yuni Kusmiyati2), Lucky Herawati2) \\ ${ }^{1)}$ Masters Program in Applied Midwifery, School of Health Sciences \\ Guna Bangsa Yogyakarta \\ ${ }^{2)}$ School of Health Polytechnics, Ministry of Health Yogyakarta
}

\begin{abstract}
Background: Relaxation aids in the reduction of stress, which can benefit the whole body. Stress causes muscle tension throughout the body, which in turn can cause the pain to worsen. Relaxation exercises help ease that built-up tension in the body, reducing pain. This study aimed to determine the effect of yoga relaxation exercise using android application on dysmenorrhea among female adolescents in Yogyakarta.

Subjects and Method: This study was a quasi experiment conducted at Muhammadiyah 5 High School in Yogyakarta. A sample of 60 female students was divided into 2 groups: yoga relaxation exercise and control groups. The dependent variable was menstrual pain. The independent variable was type of intervention: yoga relaxation exercise for 30 minutes using android application (experimental group) or leaflet (control group). The confounding variables were age of menarche, duration of menstruation, family history, and nutritional status. The dysmenorrhea data were collected by pain measurement sheet. Pain was measured by numerical rating scale (NRS). The data were analyzed using Wilcoxon test.

Results: Average pain reduction in yoga relaxation exercise group (Mean=1.73) was larger than control group (Mean= 0.95), and it was statistically significant.

Conclusion: Yoga relaxation exercise for 30 minutes using android application is effective to reduce dysmenorrhea among female adolescents.
\end{abstract}

Keywords: yoga relaxation, android application, leaflet, menstrual pain, dysmenorrhea

\section{Correspondence:}

Desi Fitriani. Masters Program in Applied Midwifery, School of Health Sciences Guna Bangsa Yogyakarta, Condongcattur, Depok, Sleman 55283, Yogyakarta.

Email: fitriadesy120@gmail.com. Mobile: 082141116057

The 5th International Conference on Public Health Best Western Premier Hotel, Solo, Indonesia, February 13-14, $2019 \mid 252$ https://doi.org/10.26911/theicph.2019.03.04 